\title{
Modeling and Perceiving
}

The theory of histospheres posits that historical films simulate historical worlds. According to Jurij Lotman, we perceive these kinds of artificial images of the (or a) world as a "model of an infinite universe," a figuration that is constantly being amended by historical experience:

The spatial image of the world created by culture is situated as it were between humanity and the outer reality of Nature and is constantly drawn to these two poles. It turns to humanity in the name of the outside world whose image it is, while the historical experience of man subjects this image to constant reworking, striving for accuracy in its representation of the world. ${ }^{2}$

Lying between these poles, a histosphere is at once a model-like representation of a historical world and both a catalyst for and product of the historical experience generated by the film. Much of its power is based on strategies of aesthetic illusion. The first section of this chapter will therefore examine the theoretical concept of figuration and the special relation between cinematic illusion and historical reference. Histospheres make historical worlds sensuously available (at least seemingly so) by constructing audiovisual, spatiotemporal structures out of aesthetically composed, narratively interfused images and sounds. In the second section, I therefore analyze the strategies used by historical films to create filmic spaces and model an internally consistent, temporally arranged historical world. I argue that filmic space is manifested in a dynamic perceptual movement,

(C) The Author(s) 2021

R. Greiner, Cinematic Histospheres, https://doi.org/10.1007/978-3-030-70590-9_5 
whose aesthetic design addresses imaginary historical references in the spectator's memory and thus anchors the living encounter with the space in a field of historical associations that also involves political interpretations and judgments. It therefore makes sense to combine my theoretical reflections on the construction of filmic space with theories of how film models and mediates history. Building on this, in the third section I propose that, for historical films, the film theory concept of mise-en-scene should be supplemented by a concept of mise-en-histoire: the imaginative referentialization of the historical worlds constructed by a film. The overarching aim of this chapter is to develop a theory of how filmic figurations are already fused with conceptions of history during the mise-en-scène process, and thereby enable historical experiences.

\section{Figuration ANd ILlusion}

When Monika walks down Kurfürstendamm for the first time in KU'DAMM 56 , the spectator is flooded with audiovisual details from the 1950s. The stores, the cars, the clothing of passersby, the bombed-out Gedüchtniskirche in the background: Moving images and sounds are woven into a complex historical world (Fig. 5.1).

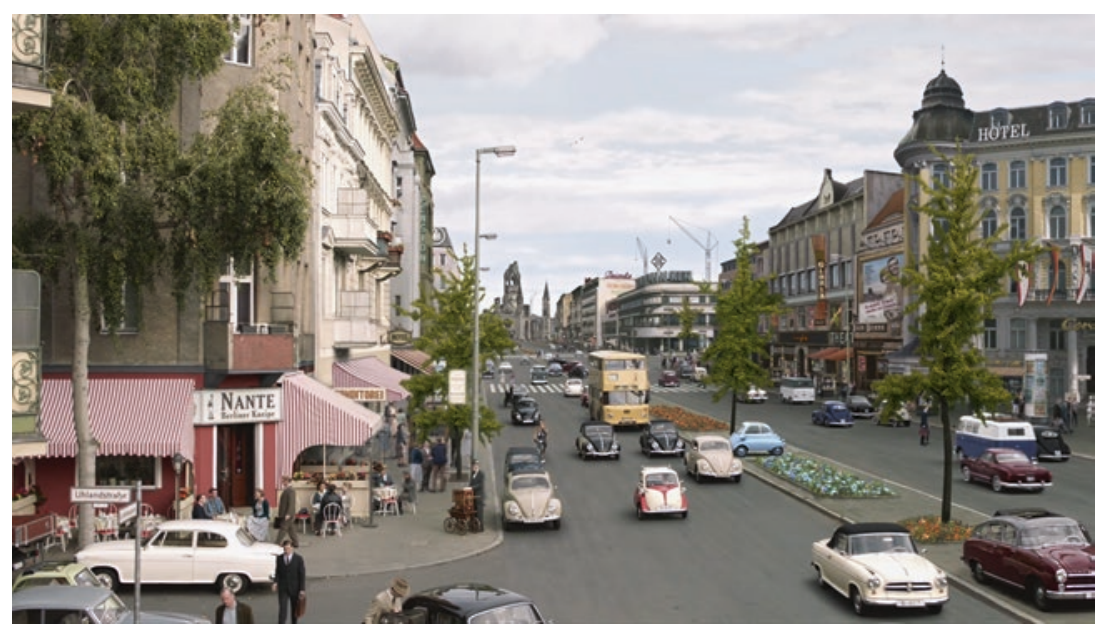

Fig. 5.1 1950s flair in КU’DАMм 56 
Against the backdrop of the linguistic turn, historian Hayden Write wrote that

It is obvious that cinema (and video) are better suited than written discourse to the actual representation of certain kinds of historical phenomena-landscape, scene, atmosphere, complex events such as wars, battles, crowds, and emotions. ${ }^{3}$

White's examples emphasize film's unique potential to not just describe a historical world but to synthesize it into an audiovisual figuration out of disparate individual elements. "Figuration" refers here to far more than the mere arrangement and constellation of the film's individual audiovisual elements in time. The concept also implies an "incarnation," a "taking form," of a word made flesh. ${ }^{4}$ Unlike in the theater, this process does not unfold in an actor's physically present body; rather, the film produces its own performative body. ${ }^{5}$ In the gaze of the film's body, a material world, the film's physical reality, is manifested. ${ }^{6}$ As a concept describing how literary works create worlds, figuration is based on a correlation between the activity of narrating a story and the temporal character of human experience. ${ }^{7}$ Philosopher Paul Ricœur defines figuration as "provid[ing] ourselves with a figure [se figurer] of the context of life [...] of the world surrounding the relic that today is missing." ${ }^{8}$ Narrative allows the historical world to be experienced in time. In his model of threefold mimesis, Ricœur shows how the "symbolic order of extra-textual reality and the worlds created in the fictional medium" enter into a "relationship of reciprocal influence and change." While "prefigurations" require us first to "preunderstand" the semantics, symbolic system, and temporality of human action, "configurations" serve a central mediating role. ${ }^{10}$ The "configurational act" produces a historical narrative as an organic whole by arranging its elements in the order of time: "It draws from this manifold of events the unity of one temporal whole."ll At the intersection between the world of the text and that of the reader, there finally occurs a "refiguration" "wherein real action occurs and unfolds its specific temporality." 12 The act of reading places the text into a relation with the reader's experiences. Ricœur understands refiguration as a process "by which the text unfolds, as it were, a world in front of itself." 13 The central element of his theory, meanwhile, is "configuration," which mediates between "prefiguration" and "refiguration," or as he puts it: "We are following 
therefore the destiny of a prefigured time that becomes a refigured time through the mediation of a configured time." 14

Applied to the concept of the histosphere, proceeding from a starting point of "prefiguration" (the spectator's prior knowledge), the "configuration" arranges the film's various aesthetic elements in time and makes it possible to experience them as a historical world ${ }^{15}$; then, finally, a "refiguration" occurs during reception of the film. In film experience, the spectator's experiences and memories blend with the audiovisually configured historical world. This results in an audiovisual form of historical experience, the special status of which can also be explained by reference to Ricour, who speaks of an "interweaving reference between history and narrative fiction." 16 While history (re)constructs the past in the reader's imagination using methods borrowed from narrative fiction, fiction in turn borrows history's "reference through traces."

Histospheres make use of this reciprocal relationship. On the basis of a fiction film's mimetic and narrative qualities, they construct an audiovisual figuration of history whose historical "reference through traces" utilizes strategies of aesthetic illusion. Illusion is understood here not as an attempt at manipulation that could lead us "to believe something that would not hold up if we were 'better informed." 18 Rather, in illusion we attain "a view of the world that does not simply distort reality, but imaginatively rebuilds it." ${ }^{19}$ Although in historical films we allow ourselves to be playfully transported into historical worlds, we never fully succumb to the illusion. ${ }^{20}$ However, this "awareness of illusion" does not disrupt it, "but serves as the framework within which the aesthetic illusion is able to unfold in the first place." ${ }^{21}$ Gertrud Koch concludes from this that film too produces a reflexive relation to the "world of appearances." 22 The fiction assumes "its own dimension of reality" that "is directed at an empirical artifact that cannot be uniquely determined but is able time and again to assume different forms in experience." ${ }^{23}$ This implies that the reflexive level of the aesthetic illusion affects how we experience and interpret the historical worlds constructed by film. In addition to its immersive, affective, and illusory potential, a histosphere creates a fluid understanding of history that leaves scope for reflection and interpretation. ${ }^{24}$ Moreover, if (as claimed by Moses Mendelssohn) artificiality creates inner coherence and appears more probable than the actual realities of nature ${ }^{25}$ this would allow us to make another connection to Ankersmit's concept of historical experience, which (as discussed in the previous chapter) he claims results from the "improbable probability" of a work of art. ${ }^{26}$ This creates a feeling 
of authenticity, which marks out the fiction as a possible world without perfecting the illusion. This has consequences for our historical consciousness, for our very knowledge that a historical film is an audiovisual figuration of historical worlds opens up deeper levels of reflection. As Koch puts it,

In the aesthetic realm, the world is conveyed by creating worlds. The central focus is not on depicting and describing the world, but on constructing worlds that can contain implicit stances toward the world. ${ }^{27}$

Following the philosopher Stanley Cavell, Koch understands film as "photographic presentations of the world set in motion." ${ }^{28}$ Analogously, histospheres can be described as "photographic presentations of historical worlds set in motion." Thus, a fundamental condition for films' construction of historical worlds is that the "fictional space of a filmic world [... builds on illusion," since "the illusorily experienced world is recognized not just as fictional but also as worldly [welthaltig: 'world-containing,' 'world-encompassing']." ${ }^{29}$ We experience a film's figuration of history as an illusion of a living historical world that is linked to our empirical world and other worlds. The cinematic illusion stands in a relation of mimesis to the prefilmic world (though without attempting to recreate that world). In historical films, this reference to the prefilmic world also includes the historical past, and so it is necessary to introduce an additional referential and reflexive dimension. The images of the world constructed in aesthetic fiction serve a commentary function, and can "refer to the empirical world in a manner not all that dissimilar from scientific fictions." 30

A histosphere thus allows us to make three sorts of hypotheses: (1) about our present-day empirical world, (2) about our conceptions of the historical past, and (3) about history as narrative construction. It also has great intuitive persuasiveness, since "the perception of movement enabled by an objective illusion becomes the signifier of a living presence that cannot be escaped." 31 A histosphere can thus produce a figuration of a living historical world that we are able to sensuously experience despite its model-like character. This marks a point of connection between the theory of histospheres and the ideas of Lotman, who regards the work of art as "a finite model of an infinite universe [...] the reflection of one reality in another, that is, it is always a translation." 32 Although Lotman is thinking here mainly of textual world constructions, one aspect of his argument does implicitly relate to the specific qualities of film. Based on an 
understanding of art as a modeling system, Lotman describes a playful mechanism based on the fact "that the different meanings of an element do not sit rigidly side by side, but 'oscillate." ${ }^{33}$ As a possible world, a histosphere is "wholly real," yet there is also no doubt that it is merely a figuration, a historical "semblant world." 34

This hybrid status is especially apparent in the depiction of historical figures, which oscillates between mimetic imitatio, that is, mere impersonation, and interpretive embodiment. ${ }^{35}$ In the historical world constructed by a film, "the actor's 'this-has-been' and the role's" 36 are augmented by a third dimension: the mythical image we have of historical figures. Our perceptions and appraisals of the depictions of historical figures and events on screen depend not just on historical discourses but also on social and cultural ones, all of which are in turn influenced by media figurations. This imaginary desideratum, rooted in our socialization and our conceptions of history (some of which are products of media), may potentially be in competition with the performative embodiment of historical figures in film. However, what is at stake here is not mere rhetorical confirmation that the depicted historical figure does not correspond to reality; rather, the tension between the film's persuasiveness and our critical reflection is part of the "game." ${ }^{37}$ By participating playfully in the modeling of a historical world, we actively contribute to the success of the illusion, without ever really forgetting that it is "only" a film.

Of particular significance for the filmic figuration of historical worlds is histospheres' referential structure. A historical film's Welthaltigkeit, the degree to which it "contains," "encompasses," or "relates to" the or a world, is measured by its imaginary historical referents. These may, like artifacts, buildings, or landscapes, actually exist in reality, but in the moment of reception they are generally absent and thus just as imaginary as all the other elements of the cinematic world. Christian Metz uses the term "imaginary referent" to describe the "piece of (imaginary) reality" from which the spectator assumes the story has been "extracted." 38 The associated "vague but strong" 99 feeling, similar to Barthes's "reality effect," 40 is manifested with particular intensity if we believe we recognize elements of the histosphere as constituents of earlier experiences. The chains of associations thus triggered very often refer to media signifiers of history that take the place of actual historical events, overlay them in our memories, and denote them as historically significant. The theory of histospheres has parallels here with historian Alison Landsberg's concept of "prosthetic memory"41: In both cases, media depictions of historical 
worlds make history accessible to wider audiences, and subsequently feel like a personal experience. Most of the "pieces of imaginary reality" to which historical films' imaginary referents refer follow this pattern and so are themselves elements of a fictional media reality. The imaginary referents of filmic figurations of history are thus also mediatized referents; the past and the historical realities simulated by media can no longer be disentangled at this level. Jean Baudrillard refers to this phenomenon as "hyperreality." For him, historical films are not representations of historical reality, but autonomous models that produce an "operational scenario of history." ${ }^{42}$ Baudrillard thus anticipates the historicizing core of histospheres, which do not reproduce the past but themselves produce history as media reality.

\section{Space, Time, and Filmic World}

The start of SKY WITHOUT STARS shows images of border fortifications, no man's land, and warning signs in rapid succession. It is not yet possible to form a coherent sense of a homogeneous filmic space, but the sequence does model a distinctively cinematic perception of space not bound by rules of central perspective. The "image space" ${ }^{43}$ visible within each individual shot functions as a segment of a spatial world accessible to sensuous experience. Slight adjustments of the camera, clouds drifting in the sky, and grass stirring in the wind reveal that these are not static images. The spectator's gaze takes in focal planes, perspectives, and proportions; it looks for clues to the spatial relations between the individual shots (Figs. 5.2, 5.3, 5.4, and 5.5).

Based on our visual experience of watching films, we anticipate a spatial structure. The credibility of this space depends not on its historical accuracy but on whether it feels right. As Simon Rothöhler puts it,

When it comes to our ability to enter into historical spaces in film, carefully placed details and the general haptic design matter more than historiographic perspectives. ${ }^{44}$

This view is consonant with Oliver Schmidt's thesis that the spectator, as a perceiving and experiencing subject, "is the link between the filmic space and the conception of a self-contained filmic world." 45

However, for a historical world to unfold in an interplay of spatial illusion, narration, and synesthetic experience requires not just a spatial but 


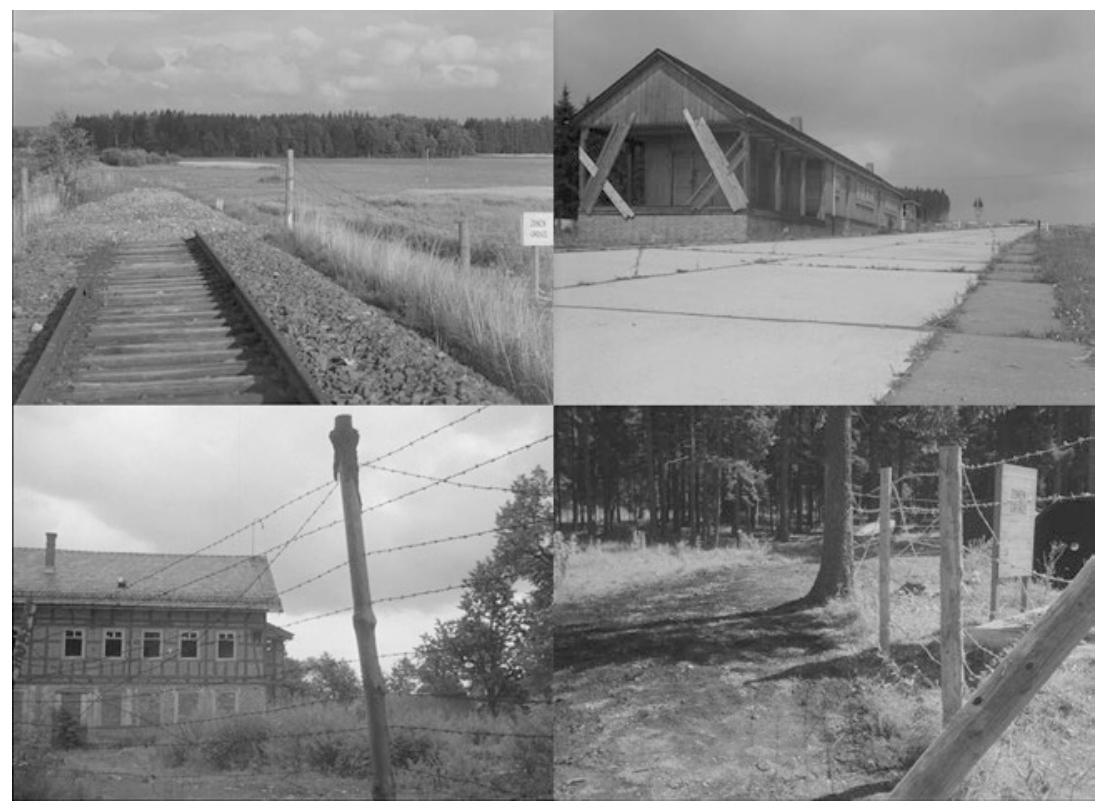

Figs. 5.2-5.5 Image space and perspective in SKY WITHOUT STARS

also a temporal figuration. In the first moments of SKY WITHOUT STARS, the time of the action appears to be standing still, and the space in which the action unfolds can only be vaguely mapped out. Only when the music briefly falls silent, the narrator dates the events to "late summer 1952," and the camera pans from the closed-off railway bridge to the river along the border do we get the impression that the filmic world is now opening up so that the narrative can begin. The camera jumps to a lightly wooded area and tilts down, following the refugees emerging from the trees. The interactions between the characters and the filmic world constitute a "space of narrative action." 46 The refugees always move from right to left. Even when the camera follows the smuggler with a long pan in the opposite direction, fixed visual points like the wood, the bridge, and the border river established at the start allow us to keep our bearings (Figs. 5.6, 5.7, 5.8 , and 5.9). The individual image spaces are connected by the movements in front of the camera as well as the movement of the camera itself, and by the audiovisual montage. The consistent light design and the establishment of an auditive space across shots create continuity. ${ }^{47}$ This 


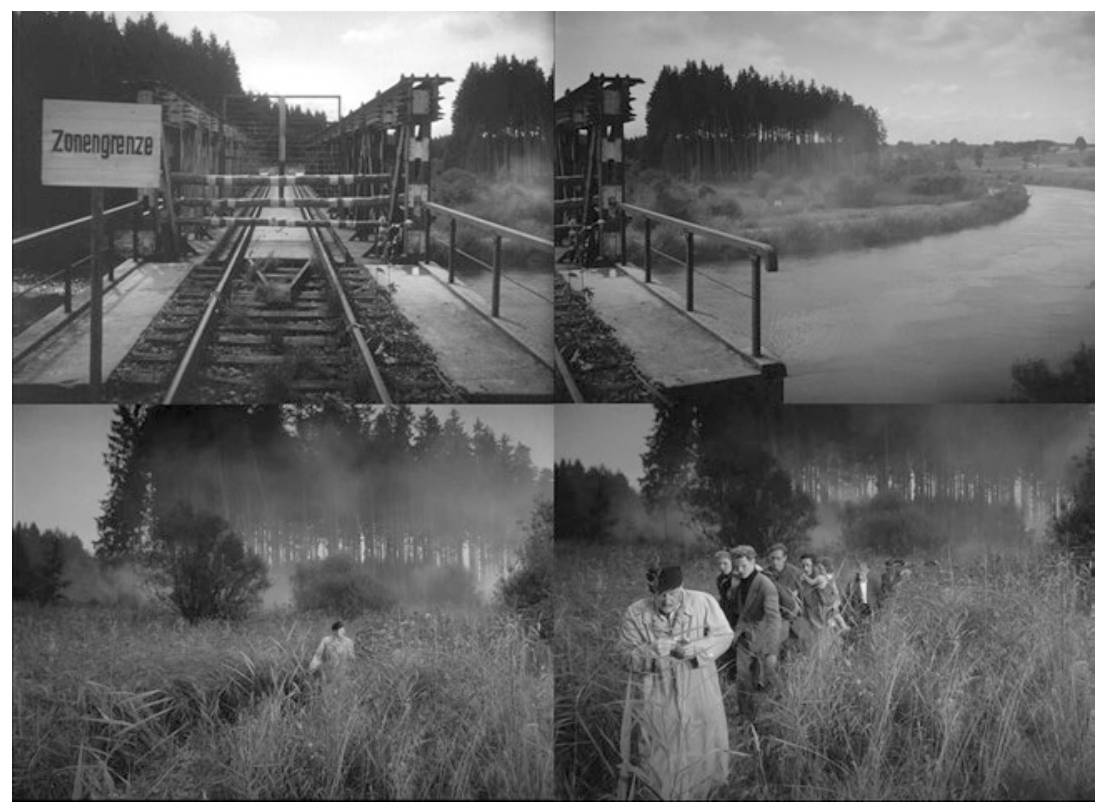

Figs. 5.6-5.9 Spatial orientation in SKY WITHOUT STARS

means the historical world configured by the film is not merely a "space of narrative action" that the characters can move about in, but also a cohesive "filmic space" experienceable by us spectators. ${ }^{48}$ The limited number of locations in which the action unfolds is in line with the narrative need for a small, bounded cosmos; however, as a filmic world, this cosmos nevertheless also points beyond itself.

A brief glance at the first few minutes of SKY WITHOUT STARS is enough to make clear the extent to which a histosphere is also a spatial phenomenon. Similar to Arnheim's distinction between "film image" and "world image," filmic space has a dual character: The concept refers, on the one hand, "to the technical act of constructing space on screen by means of stylistic cinematic devices (film image), on the other to the depiction of space as part of a complete homogeneous filmic world (world image)." 49 "Space" is an "organizing schema based on the spectator's perceptual capacity, but at the same time a specific quality ascribed to the perceived world by the spectator." 50 The filmic world is composed of the sum of individual spatial impressions: "What is experienced are concrete world spaces, that is to say, 
pieces of the world that are linked together and, as a structure of connected spaces, represent the basis for developing an all-encompassing world model." ${ }^{51}$ This is even truer of histospheres: The world spaces figured by a film are constructed segments of presupposed historical worlds, which are only pieced together in our perception of them and which we augment with our historical and cultural world knowledge. This is in accord with central ideas of the spatial turn ${ }^{52}$ in the social and cultural sciences, which according to Schmidt is generally characterized by three tendencies:

(1) Space tends to no longer be regarded as something absolute but as something relational and hence as dynamic and malleable; (2) space tends to be regarded less as a given reality and more as a synthetic product that is only realized in perception; (3) space tends to be regarded as a meaningbearing aesthetic structure that is lived and experienced by human beings and thus has a fundamentally processual character..$^{53}$

The medium of film can accordingly be understood as "a kind of cognitive and phenomenological laboratory of space" 54 in which historical worlds can be spatially and temporally modeled and opened up to synesthetic experience. The perception and form of the resulting "spatial hypothesis" 55 are dependent on aesthetic design. Schmidt therefore proposes

by way of distinction from the narratological term fictional worlds, which understands literary or cinematic worlds as systems of counterfactual states of affairs, in the case of film to also speak of aestheticized worlds, that is to say, of designed, sensuously experienced perceptual systems. ${ }^{56}$

On this view, the filmic space at the start of SKY WITHOUT STARs is not merely understood in terms of topography or coordinate systems, but is sensuously experienced. Out of the audiovisual elements of the individual image spaces, we assemble an aestheticized world. The movement of the characters and the camera and the composition of the montage allow the image spaces to interact and merge into a living encounter with the filmic space. ${ }^{57}$ Furthermore, as an effect of the figuration of movement, the filmic space "seeks to be perceived in its compositionality as something represented, that is, to be referred back to intention, meaningful structure, and expression." 58 This remark by Kappelhoff formulates a fundamental condition for conveying historicity in historical films: In order to 
be perceived as a historical world, the filmic space must first express itself as such, that is to say, it must be both sensuously available and refer to historical world knowledge.

As well as the illusion of a spatial filmic world, a histosphere also models a sociocultural space that can be assigned to a particular historical time in virtue of "cultural artifacts such as architecture, clothing, everyday objects, language, ways of behaving, specific individuals and events, and music." 59 The histosphere is by no means neutral or impartial in this process. The filmic figuration of a historical space always presents the space from a particular perspective and in a particular aesthetic, pieces it together in a particular way, and places it in relation to other filmic and historical spaces. Histospheres thus not only construct historical worlds, but also explain, interpret, and comment on them. ${ }^{60}$ To give one example, the office of Anna's factory manager in SKY WITHOUT STARs has glass doors and walls, giving a view of a large factory floor. The transparency of the glass panes not only adds another visual layer to the film image but also creates an aesthetic of surveillance that marks the GDR as a totalitarian state. A counterpart is provided by Anna's parents-in-law's cramped, densely packed grocery store, which serves as a concrete spatial expression of West Germany's consumerist market economy and small-minded bourgeois attitudes (Figs. 5.10 and 5.11). Both settings can be understood as a cinematic variety of a chronotope, in which space merges with its conventionalized functions. ${ }^{61}$ Filmic space, plot, and historical interpretation are thus expressed in a single, temporally structured experience.

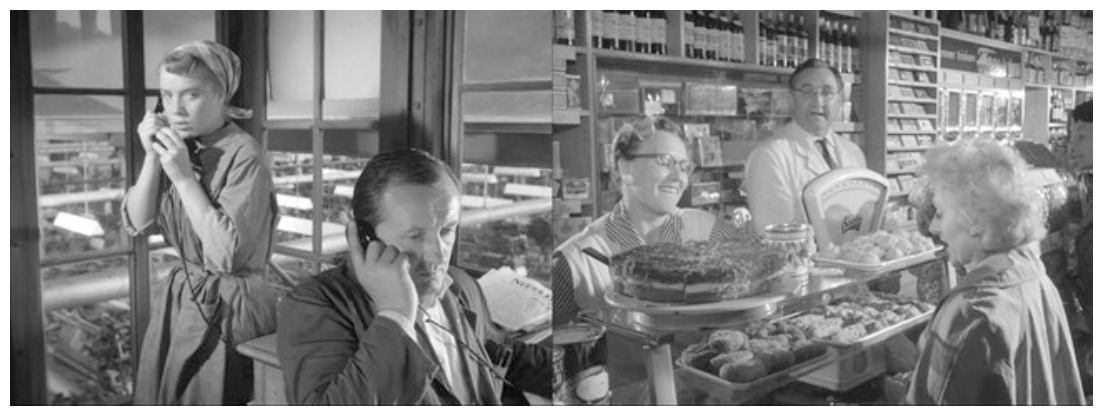

Figs. 5.10-5.11 East German surveillance and West German consumerism in SKY WITHOUT STARS 
However, it is not just the historical worlds of historical films that are inseparably bound up with a temporal dimension, but also filmic space in general. ${ }^{62}$ This interrelationship can be traced back historically: The technical, cultural, and artistic foundations of moving images date from the late nineteenth century, when space was increasingly measured in terms of time. Accordingly, the way films figure and model experientially available historical worlds depends not just on the geometric and physical construction of filmic space, but also the arrangement and realization of that space in time. Kappelhoff describes the film image as a temporal structure "that is spatialized as a perceptual world in the spectators' physically present seeing and hearing," taking up Erwin Panofsky's concepts of the "dynamization of space" and "spatialization of time." 63 This specifically filmic synthesis of space and time is especially evident in the illusion of movement: "Space itself, not the picture of space in perspective presentation is what we experience here," as Balázs puts it. ${ }^{64}$ The dimension of time allows the spectator, aided by montage and the movement of the camera, to piece the filmic space together and imaginatively move about in it. If this "imaginary movement of the body" 65 through space is understood as not just a visual and aural but also a kinesthetic phenomenon, this marks another point of connection to phenomenological approaches to film. In Sobchack's theory of film as embodied experience, a central place is occupied by the moving camera as the expression of an intentionality equivalent to a perceiving human consciousness. ${ }^{66}$ Only in this perceptual movement, anchored in space and time, can a relative off-screen space be constructed. Koch links this condition to her reflections on filmic illusion:

The camera's dual function of both producing optical-perspectival image space and constantly opening this space up to an assumed outside through movement creates the illusion that the space extends beyond what is visible. The illusory effect of this perspectivity goes beyond purely inscribing a point of view. For it is not simply the rapid alternation of locations but the possibility, suggested by the movement, of being able to move around the offscreen spaces that creates an illusory surplus. ${ }^{67}$

SKY WITHOUT STARS likewise creates the illusion of a filmic space that it is possible to "move around" in. As Anna flees from the border guards, we see long shots and medium close-ups of her crossing the river, interspersed with close-ups of a soldier shooting at her (Figs. 5.12, 5.13, 5.14, and $5.15)$. The choice of perspective is not limited to point-of-view shots 


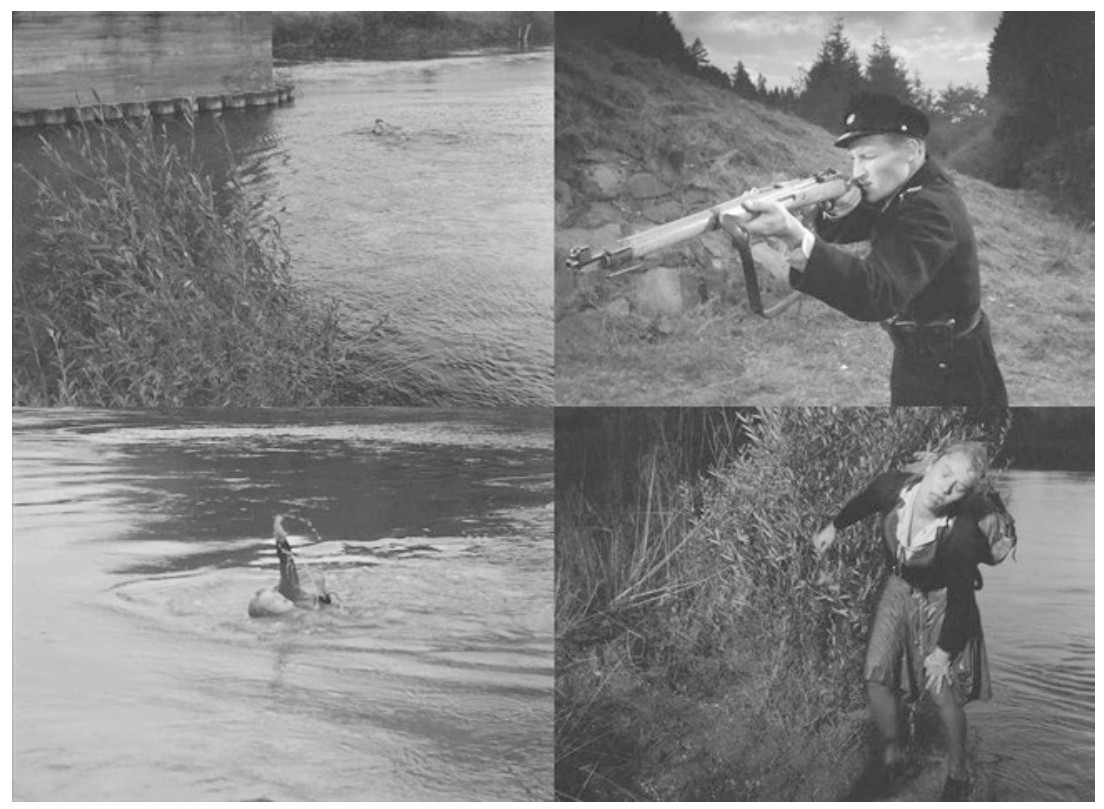

Figs. 5.12-5.15 A filmic space in SKY WITHOUT STARs in which spectators can "move around"

linked to particular characters. Quite the contrary: No location is inaccessible to the camera, even if it appears to be floating over the water. The physical laws of the "space of narrative action" matter little to the camera. Instead, the individual filmic spaces stand in a narrative chronology in which the filmic world is gradually disclosed through our perception of camera movements and montage. ${ }^{68}$ "The work grows step by step into a whole, and as we accompany its progress we must constantly hark back to what has disappeared from direct perception by ear or eye, but survives in memory," as Rudolf Arnheim writes. ${ }^{69}$ A similar form of perception can also be observed in the activity of the historian, who successively studies the available sources and relates them to each other. ${ }^{70}$

In a histosphere, this historiographical method and the film's perceptual movement are combined: In our perception, we assemble the disparate elements of the film into a historical world that we experience not just with our bodies/senses but also as a discursive system. The aesthetics of the space and the movement through the filmic world are translated into 
meaning. This production of meaning depends, inter alia, on the principles governing the movement that discloses the filmic world. ${ }^{71}$ The tripod shots at the start of SKY WITHOUT STARS convey a different experience of space than the shaky handheld shots in the famous Omaha Beach sequence in SAVING PRIVATE RYAN (1998; dir. Steven Spielberg). Both films use classic shot-reverse shot montages and consistent directions of movement. But although the filmic spaces are constructed in a similar way, the way these spaces are experienced differs. While in SKY WITHOUT STARS we can calmly observe the characters' actions in an already-constructed filmic space, in SAVING PRIVATE RYAN the filmic space is constructed by the characters' movements, which sweep the spectator along with them. To a much greater extent than in SKY WITHOUT STARS, the camera appears to be subject to the physical forces of the filmic world, so that whereas in Käutner's film the historical world is primarily observed, SAVING PRIVATE RYAN constitutes a space of extreme physical experience. What this shows is that histospheres do not just illusorily reconstruct historical spaces, but also "use the movement of images to create a spatial experience sui generis," 72 which forms the film's historical worlds out of its perceptual movement. ${ }^{73} \mathrm{~A}$ histosphere makes us feel as if we are traveling back in time. The illusory experience is often so strong that the end of the film represents not merely a dramaturgical closure, "but, in a broader sense, the possibility to either switch off an entire world-or disseminate it outside [the movie theater]." ${ }^{74}$ Put another way: Just as the filmic space is assembled over a passage of time, it disappears again at the end of the film. However, the way the film's historical world is perceived and experienced leaves traces that are inscribed in our conceptions and interpretations of history.

A special relation between space and time also exists at the level of film sound. To an even greater extent than the moving image, which stands in a relation of similarity to the static single image, sound can only be perceived over a passage of time. The specific arrangement of film sound in time plays a key role in cohering the separate image spaces into a homogeneous filmic world. Ordered autonomously alongside the images, sound bridges cuts and creates spatial continuities. ${ }^{75}$ One example of this effect is when Anna, following her dramatic escape over the river, meets the border guard Carl Altmann for the first time. The continuous chirping of crickets links the individual shots together into a homogeneous space in which the action plays out. The ambience ${ }^{76}$ mediates between depiction and perception: It models the filmic space and infuses it with a mood capable of affecting the spectator emotionally. ${ }^{77}$ Sound can also create an off-screen 
space of varying sizes. ${ }^{78}$ In Anna's parents-in-law's grocery store, at first we can only see Otto Friese (Gustav Knuth) serving a customer outside the entrance. But when we hear his wife Elsbeth (Camilla Spira) talking to another customer at the checkout, we form an imaginary picture of the inside of the shop before we can see it. The world of a histosphere is constructed not just by sight but also by sound. The soundtrack's "instant credibility" makes the illusion of space feel believable. ${ }^{79}$ Balázs observed that the particular "timbre" of sound can give us the impression of being in the midst of the depicted events. ${ }^{80}$ Noises in particular can give the filmic world substance and a haptic quality. ${ }^{81}$ Film sound can also situate the action in a particular historical period. ${ }^{82}$ The characteristic chime of the cash register in Otto's store, for instance, can be dated fairly confidently to the mid-twentieth century. ${ }^{83}$ While from individual noises it may only be possible to get a very imprecise sense of where and when a film is set, we will get a clearer idea once multiple sound objects are arranged into complex soundscapes: The whirring, squealing, and clattering of the car, the voices of the passengers, and the crackling PA system at the start of KU'DAMM 56 allow us to recognize the Berlin subway train. ${ }^{84}$ But only in combination with film images can the setting be identified as the 1950s. A histosphere's world is based on an audiovisually configured, perceptually constructed spatiotemporal structure that develops added value through the specific interactions between image and sound. ${ }^{85}$ The image spaces constructed by a film and the historical worlds assembled in the spectator's temporally structured perceptions are thus not the sum but the product of visual and aural stimuli.

The relation between filmic space and characters also influences the constellation of characters. While many historical films adopt the single- or dual-protagonist structure that has dominated throughout film history, there has been a tendency in more recent examples toward larger ensembles, allowing the historical world constructed by the film to be explored from multiple perspectives. This can already be seen in SKY WITHOUT STARS, which augments the traditional structure, based around a single central couple, with other key characters. Anna's frail grandparents on one side of the border and her parents-in-law and son Jochen on the other form a dual structure in which East and West are historicized as a spatial order. There is a tendency away from a classical, "temporally causal, psychologically motivated narrative trajectory directed at compromise" toward a spatially organized structure. ${ }^{86}$ This early example heralds the emergence of "a different logic of narration," which Margrit Tröhler connects to the 
growing trend for films with "plural character constellations." ${ }^{87}$ According to Tröhler, these films are "bound less to individual, binary positions than to relational dynamics, preferring flat or fluid structures, the differentiation of values, and inconclusive negotiation of contradictions." ${ }^{88}$ No satisfactory dramaturgical resolution is achieved in our specific example either; instead, Anna and Carl drift back and forth between the topographical coordinates of divided Germany, without being able to bridge this divide. The third space, the no man's land between the barriers of the inner German border into which the lovers retreat for a brief time, ultimately proves to be an illusion. While SKY WITHOUT STARS only gestures toward plural character constellations, ensembles like that in KU'DAMM 56 usually have a spatial center that exerts "a centripetal force on the narrower and broader circle of its members," incorporates them into the same heterogeneous constellation, and brings them together at a central location. ${ }^{89}$ In KU'DAMM 56, one such "chronotope of encounter" 90 is constituted by the Galant dance school, where the characters' paths are constantly crossing, conflicts play out, and hardships are endured. The spatial dimension of this culminating point is also supplemented by a historical one, for it gradually emerges that the school was confiscated from its previous Jewish owners under the Nazi regime and given to the Schöllack family. KU'DAMM 56's serial structure is one key factor that enables these sorts of "complex narrative forms, which are connected to a broad ensemble of characters." $" 11$

Another form of plural character constellation is the character mosaic. Many and diverse characters are arranged within a complex narrative structure, but mostly do not know or interact with each other. ${ }^{92}$ This sort of constellation can already be found in episodic films like Helmut Käutner's IN THOSE DAYS (IN JENEN TAGEN, 1947), which is temporally and spatially organized around the changing owners of a single car. In the multilayered construction of a more recent film like DUNKIRK (2017; dir. Christopher Nolan), the spatial dimension comes even more strongly to the fore. The flow of the linear narrative is interrupted by jumps in time and the repetition of the same events from different perspectives. The film's narrative structure is reorganized based on the characters' spatial configuration, in the manner of a scientist setting up an experiment. This high degree of artificiality openly declares the simulated historical world "to be an imaginary construction, and the interconnecting narrative plays with 'relations' of all kinds - structural, semantic, plastic - thereby heightening the films' expressivity." 93 A histosphere is consequently experienced 
not just as a historical world but also as a model, a figuration of such a world. At the same time, plural character constellations often appear "to borrow from the social dynamics and patterns of everyday experience." 94 Historical films and television shows whose simulated worlds differ especially sharply from the spectators' day-to-day reality also tend to place particular emphasis on figurations that link the film's historical world to familiar iconographies and the spectators' embodied memories. ${ }^{95}$ Moreover, by contrast with many biopics and classical historical films, films with plural character constellations often dispense with traditional heroes and develop, as "cultural praxis," different modes of encounter with the Other. ${ }^{96}$ The open historical worlds created by this approach foster a changed experience of history. An intense sense of contingency undermines the experience of determinism that may be engendered by the spectator's knowledge of history. A plural character constellation allows the depicted historical processes to be explored from multiple perspectives and lived as undetermined, contingent, present events.

\section{From Mise-En-SCÈne to Mise-EN-Histoire}

The inside of a subway car: passengers in long coats, almost all of them wearing hats, the women in skirts, the men in jackets and cotton pants. Spread evenly throughout the space, framed by brass handrails and light brown wood paneling, they stand or sit, reading newspapers or staring mutely into space. A young man is reading an article about an Elvis concert out loud, accompanied by the even whirring, clattering, and squealing of the train and the subtle piano tones of the score. Lamps with domed milk glass covers douse the scene in a diffuse light, which further accentuates the brown and gray tones of the decor and costumes (Fig. 5.16). After just a few seconds, we know that this sequence from the start of KU'DAMM 56 is set in the past. A historical world is staged for our eyes and ears, which is given particular intuitive persuasiveness by the interactions between the film's aesthetic operations and our perception.

The way we perceive the simulated historical world in a film is based, first and foremost, on the arrangement and organization of characters in space and the structuring of spatial relations in time: in short, on the miseen-scène, which constitutes the filmic space, organizing "all visible and audible elements, both intraframe and interframe." 97 The choice of camera angles, the image composition, and the sound design are geared toward the logic of the later montage. ${ }^{98}$ The mise-en-scène thus directs our 


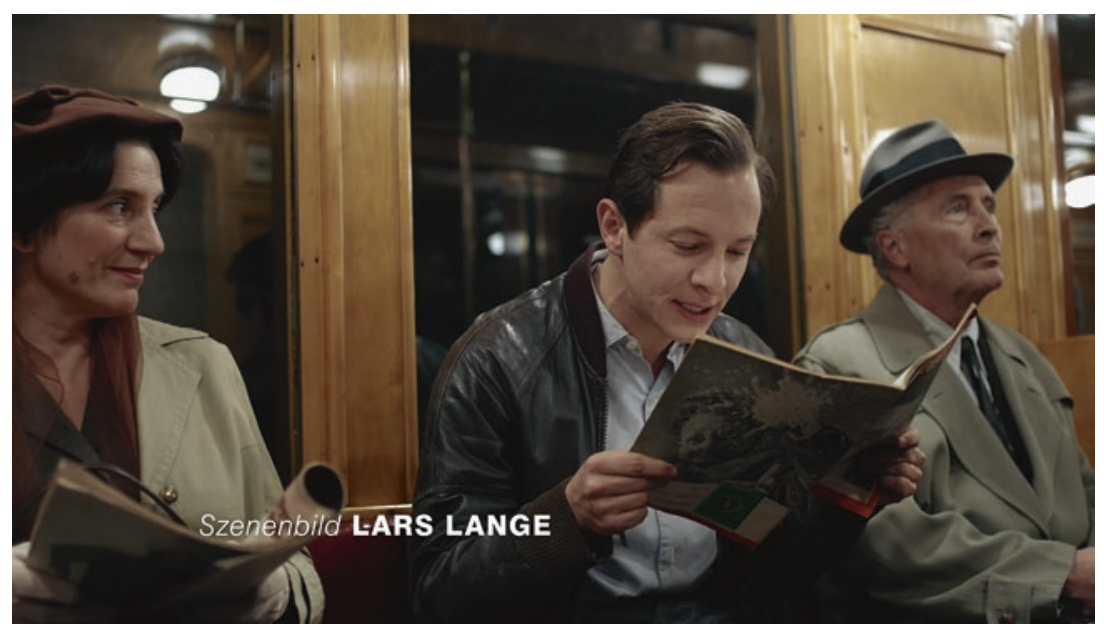

Fig. 5.16 Staging of history in KU'DAMM 56

perceptions both within and between the frames. ${ }^{99}$ The effect of a threedimensional filmic space is created only "through artistically arranged [inszenatorische] connections between the visual structures." The mise-enscène constructs this effect "by means of recessive compositions, sculptural lighting, or alternating camera perspectives." 100 Although this description is focused on the visual level, we should not forget that filmic space is also shaped by sound. ${ }^{101}$ Through the interplay of film image and film sound, the mise-en-scène opens up an audiovisual space of events that not only structures the filmic world aesthetically, but also communicates it audiovisually. ${ }^{102}$ Mise-en-scène thus proves to be an essential concept for the theory and praxis of histospheres. If a histosphere is a filmic figuration of a historical world, mise-en-scène is its "sensuously tangible texture."103 It oscillates between signifying practice and mediating entity; Ivo Ritzer writes that the mise-en-scène "does not relay a fixed meaning from senders to receivers, but rather opens up a discourse between these poles, which in the process of media signification are both constructed and contained within it." 104 Applied to historical films, this means that in the interaction between artistic arrangement and perception, the mise-en-scène configures a historical world while also being part of the form of representation. ${ }^{105} \mathrm{~A}$ histosphere is not just a representation of a historical world, but also a discursive construction and performative act. 
Our ability to perceive the historical filmic world organized by the miseen-scène as historically connoted is, in turn, connected to a special process of referentialization. I call this process mise-en-histoire. Mise-en-histoire referentializes the world formed out of the film's audiovisual figurations in popular historical consciousness and reciprocally links it to the spectators' individual conceptions of history. ${ }^{106}$ While the mise-en-scène organizes the performative act of staging and the world created by it, and makes this world and act experientially available to spectators, the mise-en-histoire establishes a relation to collective and individual conceptions of the historical past. Experiencing a histosphere thus involves not just perceiving a historical world constructed by the film, but also the associations triggered by it. The potential historical meanings and references manifested in this process in turn have multiple layers. For instance, the aesthetic design of the figurative surfaces also simulates historical aesthetics, representational practices, and media technologies. ${ }^{107}$ In KU'DAMM 56, for example, the colors look slightly faded, reminiscent of old photographs from the 1950s (Figs. 5.17 and 5.18). This reference to historical media not only gestures toward other media signifiers of historicity but also connects to the spectator's own mental pictures, which may be based on media experiences but are not necessarily consciously linked to them. In this way, the mise-enhistoire invests a histosphere with a relational temporality and a spatial structure organized within this temporality. ${ }^{108}$

In terms of narrative theory, this schema is reminiscent of Mikhail Bakhtin's concept of the "artistic" or "literary chronotope," which fuses "spatial and temporal indicators [...] into one carefully thought-out, concrete whole." 109 Space and time are interwoven:

Time, as it were, thickens, takes on flesh, becomes artistically visible; likewise, space becomes charged and responsive to the movements of time, plot and history. The intersection of axes and fusion of indicators characterizes the artistic chronotope. ${ }^{110}$

Consequently, in their "correlative combination" space and time generate "a new tertia and gain in materiality and plasticity." 111 Bakhtin's reflections are focused on the novel, but can also be applied to film. While mise-en-scène comprises the arrangement of characters in space and time, mise-en-histoire interweaves them with popular historical narratives. This narrative dimension of histospheres affirms Hayden White's thesis that history is necessarily narrative. ${ }^{12}$ Furthermore, the historical referentiality 


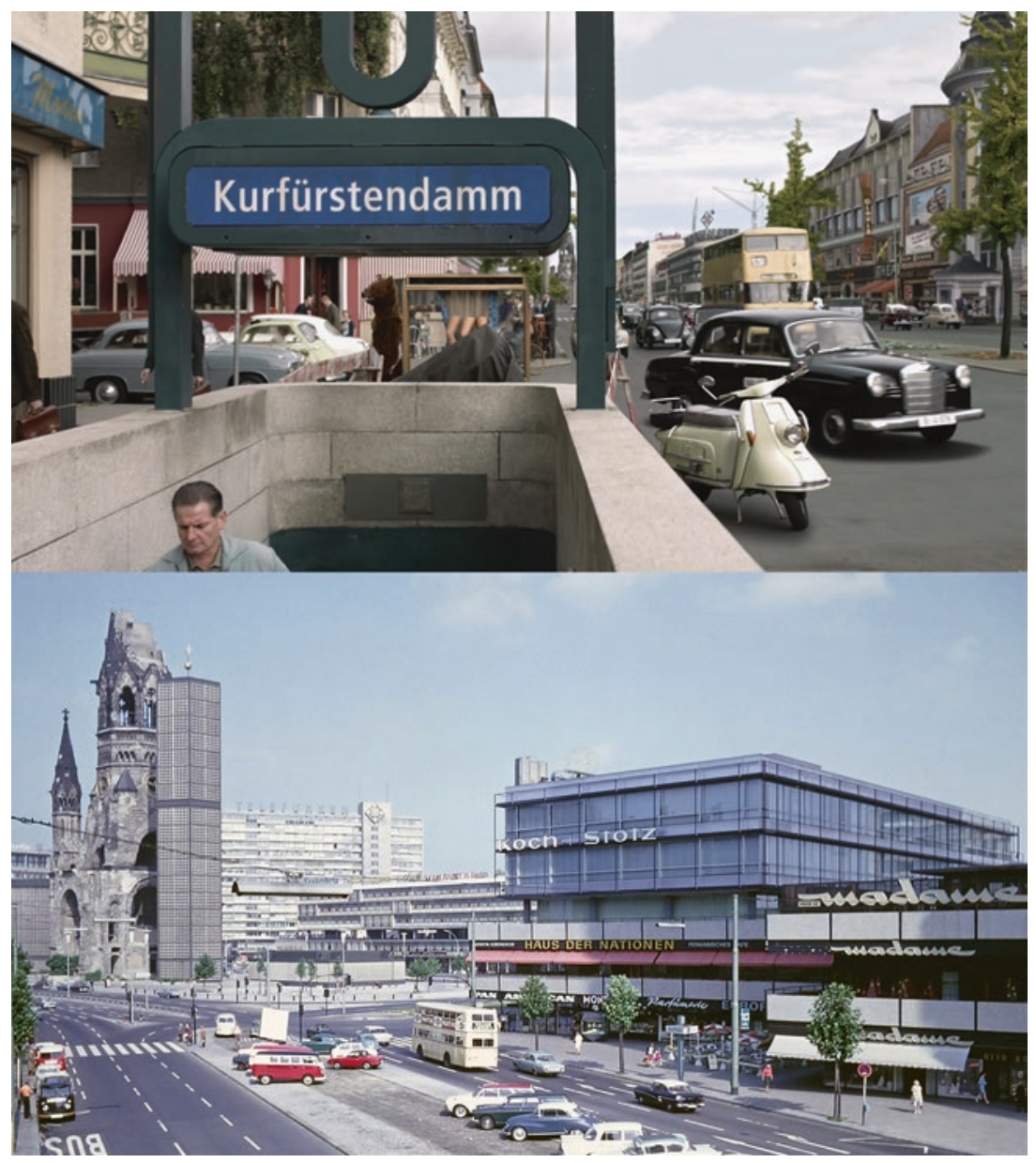

Figs. 5.17-5.18 Faded colors in KU'DАMм 56 and in a contemporary photograph

of visual and aural elements of film grants us an intentional mode of access to history that interacts with our media-influenced conceptions of history. The notion of a chronotope, referring to a narrative "increase in density and concreteness of time markers - the time of human life, of historical time-that occurs within well-delineated spatial areas" that serve as the "primary point from which 'scenes' [...] unfold," 113 is thus also highly 
relevant for historical films and can be understood as the spatiotemporal nucleus of the mise-en-histoire, the process of historical referentialization.

The mise-en-histoire is also closely interwoven with aesthetic design. When the mise-en-scène "tells and shows," when it creates "content through form," "Lighting, scenery and decoration, costumes and make-up, bodies and objects"115 —all aspects of the mise-en-scène are geared toward the gaze of the camera. As an integral part of the mise-en-scène, the camera gives "the arrangement of scenic elements in space its specific effect" and creates "new spatial relations." 116 The camera synthesizes all the visual elements of the filmic world. The way in which it captures and represents the depicted space and the characters arranged within it determines how we perceive them. In an early scene in KU'DAMM 56, the camera tilts up from the floor of the dancehall, accompanied by the soaring orchestral tones of Don Cornell's "Most of All." Dance teacher Caterina Schöllack (Claudia Michelsen) strides directly toward us between lines of smartly dressed young people. The strict central perspective is underscored by the visual layers stretching back into the depths of the image. When Caterina turns around directly in front of the camera, the film cuts to a reverse angle. A crabbing shot follows her as she makes her way back through the lines to her starting point, interrupted by over-the-shoulder perspectives that link back to the first shot of the sequence. The mise-en-scène depicts the dance school as if it were a military drill ground (Figs. 5.19, 5.20, 5.21, and 5.22). In combination with the mise-en-histoire, this sets up the way the series will present the 1950s: as a struggle between the restoration of social order and the younger generation's yearning for freedom. To the beat of Cornell's ballad, the sequence's audiovisual choreography explores the characters and space, and casts them into a certain picture of history. Directed toward "the externalization of an inner expression," 117 the camera constructs a historical world. "By modeling, it delineates, accentuates, interprets"118 that which lies before it.

The camera structures the perceptions of the spectating subject and prefigures their reception "by seeking to have the pro-filmic gaze coincide with the filmophanic image that is projected or broadcast onto the screen." 119 This can also be seen in the depiction of the eponymous Kurfürstendamm, Berlin's famous shopping boulevard. At the start of KU'DAMM 56, a crane shot lowers us into the historical scenery. The camera then tracks back as we watch Monika walking through the film's constructed 1950s reality: stores with awnings and neon signs in the style of 


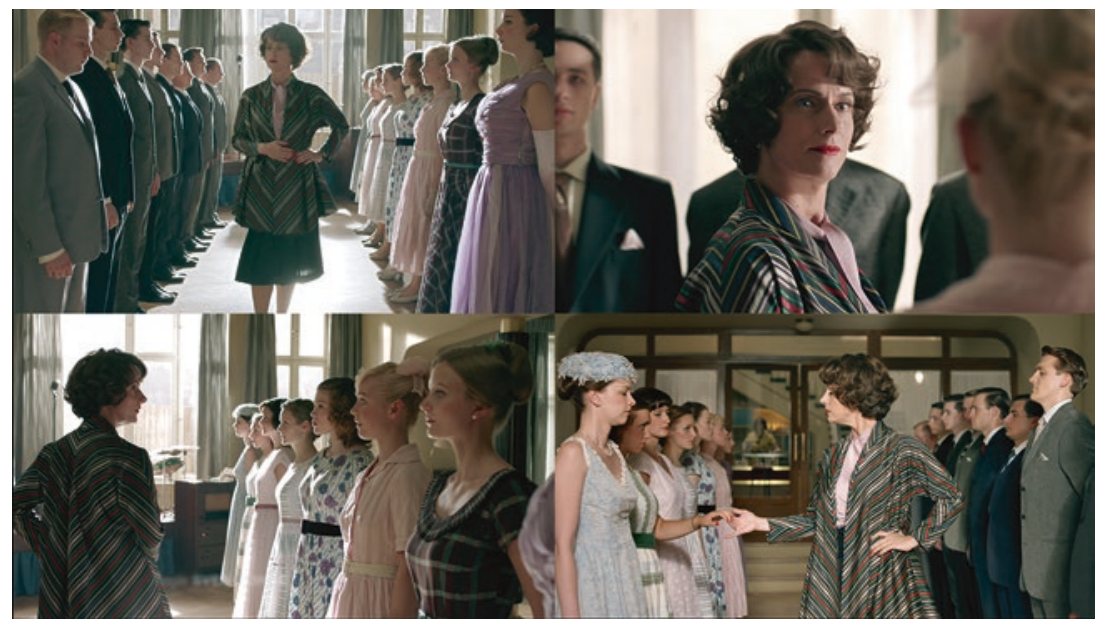

Figs. 5.19-5.22 Dance class or military drill? Mise-en-scène in KU'DAMM

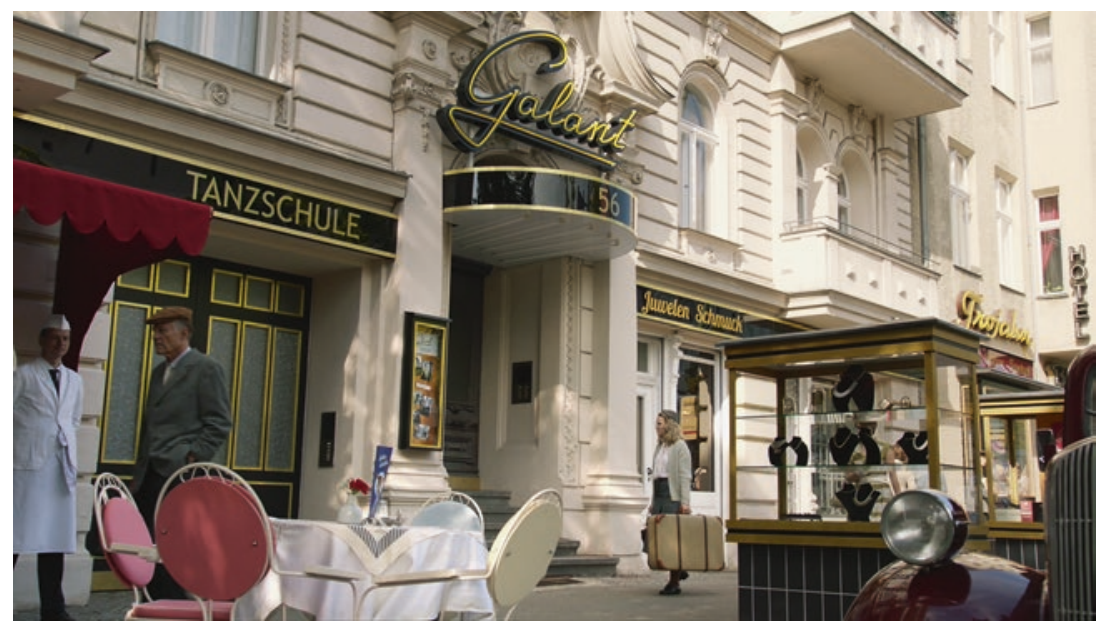

Fig. 5.23 The film's historical world in KU'DAмм 56 
the period, advertising pillars and display cases, passersby and sales clerks in authentic costume (Fig. 5.23). The mise-en-scène prefigures the histosphere's spatial coordinates, which the spectator assembles in their mind into a coherent historical world. The space of the historical world generated by the film is thus always an interpretation of the spatial arrangement of elements, which in turn is enriched by the spectator's memories and associations. However, we are not simply passively subjected to this intentional perspectivation: On Sobchack's phenomenological theory of film, the way film arranges its various elements is based around a dual structure of seeing and being seen. ${ }^{120}$ With the gaze of the cinematic subject, the camera addresses the gaze of the spectator, which perceives the film images both as the presented world and as an intentional point of view on that world. ${ }^{121}$ Our perceptions of a histosphere also oscillate between pleasurably exploring a depicted past and observing (though no less appreciatively) the arrangement of audiovisual elements itself. Sobchack's concept of a doubled gaze thus also enables a re-perspectivation that casts a new light on historical filmic worlds.

Relation to reality is a significant aspect of both mise-en-scène and the historical film genre. For instance, the paratextual information that a film was shot in "original locations" creates a feeling of authenticity; we implicitly believe that traces of a-filmic reality will have been inscribed into its histosphere, which would imply that the use of original locations creates something like a Benjaminesque aura. However, the reproducibility of the medium of film casts doubt on this. ${ }^{122}$ The theory of mise-en-scène holds that a-filmic reality merely provides "raw material for the pro-filmic," which comprises "all elements of an image that are situated before the camera and intentionally recorded by it for the purpose of media transmission." 123 This formulation leaves it open whether at least the unintentionally recorded elements of film images or film sound should not also be assigned to a-filmic reality. But here too the "camera's ineluctable molding process" takes effect, giving all elements in the "event space" the status of scenery. ${ }^{124}$ Put another way: Everything that we see and hear, including in historical films, even what the camera and sound equipment have recorded unintentionally, is per se artificial and synthetic. The indexical connection to a-filmic reality can exist only as interference, as the "noise of the real." 125 Film images thus have a dual status: Firstly, they can be defined as aesthetic images in isolation from anything external to them; secondly, "they are characterized by their reference to an external totality, whose continuous alteration they articulate as duration over time."126 Mise-en-scène and 
mise-en-histoire are thus based on the same principle: They make "that which is absent medially present on the screen." 127 However, their referents differ in terms of time: While the referent of the mise-en-scene is the a-filmic reality at the time of filming, the referent of the mise-en-histoire is an imaginary historical point of time. Two layers of historicity overlap, creating a hybrid form of temporality.

This opens up scope for interpretation concerning the depicted historical location. It is often not possible to identify the filming location from the film images. Mise-en-scène transforms places into aesthetic units. The camera's gaze turns "even a-filmically existing places into scenic elements, by imposing a particular perspective on them." 128 This means that the history of films' production is sometimes rather surprising. KU'DAMM 56, for instance, was not filmed in "original locations." For aesthetic and logistical reasons, the eponymous boulevard had to be moved to a different street, which was transformed into the historical setting by means of set design and postproduction. ${ }^{129}$ Even the ruins of the Gedächtniskirche were inserted into the background later on. This shows that the feeling of authenticity that creeps over us when we enter into a film's historical world is more an effect of how the elements are arranged and staged than an indication of an actual indexical link to history, and that histospheres, incorporated into specific social and cultural constellations and their historicity, are the product of a "creative camera" that does not simply reproduce historical images but imprints a particular "vision" on them. ${ }^{130}$

Audiovisual figurations of historical worlds can also be viewed critically. For instance, Fredric Jameson complains of "aesthetic colonization" in which in-depth historical discourses have been replaced by the historicity of an audiovisual style. ${ }^{131}$ On this view, a histosphere would be little more than an aesthetic attribute. However, Jameson misunderstands the complex historicity of film described by authors such as Jacques Rancière. ${ }^{132}$ Jameson's overly simplistic attempt to pit "real" history against "fake" history also overlooks the divergence between, and processual character of, different approaches to history. Kracauer, by contrast, sees in the misguided intention to "reproduce" the past in all its complexity a structural parallel between history and "camera-reality," which are both "partly patterned, partly amorphous." 133 He says that both history and film challenge their "adepts" to "capture a given universe." ${ }^{34}$ Histospheres unite these two approaches through the combination of mise-en-scène and mise-enhistoire. However, while the concept of "camera-reality" refers solely to the historical point in time at which an image was produced, a histosphere 
has twofold access to history: Firstly, it is linked to the time of the film's production by the historicity of the aesthetic design. Secondly, the film's depiction of a historical period also refers to a larger historical referent and its myriad representations in media. A histosphere is thus a kind of puzzle picture in which different layers of the past overlap. At the same time, it conveys an intense feeling of being-in-the-world. The synesthetic quality of the filmic staging gives the simulated historical world a sensuously tangible materiality. For film scholar Anne Rutherford, mise-en-scène is the crucial link between cinema's material dimensions and affective potential. ${ }^{135}$ As a "synthesizing aspect," mise-en-scène connects the filmic staging to "the spectating subject's corporal perception." 136 The resulting "body of media experience" 137 can once again be connected to Sobchack's phenomenological reflections on the film's body. ${ }^{138}$ Sobchack describes an incarnated perception, a film's embodied perspective on the filmic world that the spectator can both view from the outside and live through and interoceptively experience themselves. ${ }^{139}$ Mise-en-scène models the film's perspective and conveys the cinematic space as a "lived space." ${ }^{140}$ Building on this process, the historical film produces a living relation to subjective conceptions and popular representations of history through a synthesis of artistic arrangement and modeling, embodied film experience, and miseen-histoire. A histosphere's simulated historical world becomes a lived world: We are put into a mode of embodied, living encounter with history.

\section{Conclusion}

In this chapter, I attempted to develop a concept of histospheres based on filmic figurations. The worlds modeled using the devices of film design are already fused with conceptions of history during the mise-en-scène process, enabling a living, physically palpable encounter with the past. Histospheres are thus both a catalyst for and product of the historical experiences generated by films. To provide a theoretical underpinning for this thesis, I drew on Paul Ricœur's notions of prefiguration, configuration, and refiguration to show how the spectator's experiences and memories blend with the audiovisually configured historical world. ${ }^{141}$ On the basis of fiction film's mimetic and narrative qualities, histospheres construct audiovisual figurations of history whose historical "reference through traces" utilizes strategies of aesthetic illusion. We allow ourselves to be playfully transported into historical worlds, but they always remain identifiable as artificial, artistic constructs. 
Histospheres therefore create a fluid understanding of history that leaves scope for reflection and interpretation. This allowed me to draw a connection to Ankersmit's concept of historical experience, in which he claims that it is the "improbable probability" of a representation of history that makes it believable. ${ }^{142}$ It is precisely because we are aware that historical films are audiovisual figurations of historical worlds that we are able to engage in more in-depth reflection. Consequently, in addition to the relation of mimesis in which cinematic illusion stands to the prefilmic world (though without attempting to imitate that world), we must also introduce another referential, and reflexive, dimension. Histospheres thus allow us to make three sorts of hypotheses: (1) about our present-day empirical world, (2) about the actual historical past, and (3) about history as narrative construction. In combination with the enormous intuitive persuasiveness and presence of audiovisual media, they can produce figurations of living historical worlds that we are able to sensuously experience despite or even precisely because of their model-like character.

Based on this and Christian Metz's work, I observed that a historical film's Welthaltigkeit (literally, the degree to which it "contains" or "encompasses" a living world or the world) is measured by its imaginary historical referents. Most of the "pieces of imaginary reality" to which historical films' imaginary referents refer are in turn based on media depictions of historical worlds. These depictions make history accessible to wider audiences, and subsequently feel like a personal experience-a phenomenon for which Alison Landsberg coined the term "prosthetic memory." 143 "Referential realism" gives way to a "perceptual realism" 144 constituted by the subject's mediatized experience of history. This makes film part of a new mode of history that draws on an archive ${ }^{145}$ of hyperreal histospheres.

To get a full picture of the effects of histospheres, I showed that they also involve spatial phenomena. As world spaces figured by films, histospheres are constructed segments of presupposed historical worlds, which are only pieced together in our perception of them and which we augment with our historical and cultural world knowledge. As well as the illusion of a spatial filmic world, which we experience corporeally and sensuously, histospheres also model sociocultural spaces. The film's historical worlds are integrated into a discursive nexus that shapes, comments on, and interprets them on the basis of the film's perceptual movement. The way we perceive and experience histospheres leaves traces that are inscribed in our conceptions and interpretations of history. 
One particular focal point was the intersection between artistic arrangement and historical referentialization. In order to better describe and conceptualize the relevant relations, I introduced the notion of mise-en-histoire, based on the film theory concept of mise-en-scène. While the mise-en-scène describes the performative act of staging, whereby filmic worlds are organized and made available to experience, the mise-en-histoire establishes a relation to collective and individual conceptions of the historical past. The historical referentiality of visual and aural elements of film evokes an intentional mode of access to history. These associatively recalled conceptions of history often refer to prior media experiences. Histospheres are thus invested with a relational temporality and a spatial structure organized within this temporality.

By reference to Sobchack's phenomenology of film experience, I observed how our perceptions of a histosphere oscillate between pleasurably exploring a depicted past and observing (though no less appreciatively) the arrangement of audiovisual elements itself. ${ }^{146}$ Sobchack's concept of a doubled gaze enables a re-perspectivation that casts a new light on historical filmic worlds. On this view, the feeling of being able to immerse ourselves in a historical world through film is a product of miseen-scène and mise-en-histoire rather than a sign of any actual indexical connection to history. Linked to the time of a film's production by the historicity of the aesthetic design while simultaneously referring to an imaginary historical referent and its myriad representations in media, histospheres thus function like a puzzle picture in which different layers of the past overlap. The synesthetic qualities of the medium of film give the simulated historical world a sensuously tangible materiality. Sobchack describes a film's embodied perspective on the filmic world ${ }^{147}$ that we can both live through ourselves and link to our conceptions of the past. A living relation to history is established through a synthesis of artistic arrangement and modeling, embodied film experience, and mise-en-histoire; in the next chapter, I shall explore this relation and its workings in further depth.

\section{Notes}

1. My concept of "modeling reality" applies Lotman's notion of art as a "modeling system" to fiction film while taking account of the significant differences that exist between the mediums of film and literature, especially with regard to synesthetic sensuous experience. See Jurij Lotman, The Structure of the Artistic Text, Ann Arbor 1977, p. 210. 
2. Yuri [Jurij] M. Lotman, Universe of the Mind: A Semiotic Theory of Culture, Bloomington and Indianapolis 1990, p. 204.

3. Hayden White, "Historiography and Historiophoty," American Historical Review 93:5, 1988, p. 1193.

4. I am drawing here on the work of literary theorist Erich Auerbach, who derives the concept of "figuration" from Augustine's figuratio. Erich Auerbach, Mimesis: The Representation of Reality in Western Literature, Princeton 2003.

5. See Vivian Sobchack, The Address of the Eye: A Phenomenology of Film Experience, Princeton 1992, p. 169.

6. Siegfried Kracauer speaks of film's "reality character," to which "the spectator cannot help reacting $[\ldots]$ as he would to the material aspects of nature in the raw which these photographic images reproduce." Siegfried Kracauer, Theory of Film: The Redemption of Physical Reality, Princeton 1997, p. 158.

7. Paul Ricœur, Time and Narrative, vol. 1, Chicago and London 1984 (hereinafter Ricœur 1984), p. 52.

8. Paul Ricœur, Time and Narrative, vol. 3, Chicago and London 1985, p. 184.

9. Astrid Erll, Kollektives Gedächtnis und Erinnerungskulturen: Eine Einführung, Stuttgart 2011, p. 180.

10. Ricœur (1984, pp. 64-65).

11. Ibid., p. 66.

12. Ibid., p. 71.

13. Ibid., p. 81 .

14. Ibid., p. 54.

15. This process is analogous to that of mise-en-scène, which I discuss in more depth in the section "From mise-en-scène to mise-en-histoire."

16. Ricœur (1984, p. 82).

17. Ibid.

18. Gertrud Koch, Die Wiederkehr der Illusion: Der Film und die Kunst der Gegenwart, Berlin 2016, p. 24.

19. Ibid.

20. Koch observes that we are predisposed to certain types of illusion, such as the filmic illusion of movement, and so are not in danger of mistaking them for reality. Ibid., p. 39.

21. Ibid., p. 43.

22. Koch is paraphrasing Mendelssohn, who believed that aesthetic illusion affords us privileged access to the truth: "The fiction [das Erdichtete] is characterized by a vivid clarity [Anschaulichkeit] conducive to understanding; this clarity comes from the fiction's distance from nature." Ibid., pp. 51-52. 
23. Ibid., p. 44. Makers of propaganda films have often attempted to undermine the medium's reflexive openness.

24. Here too I am following Koch, who applies Mendelssohn's theory to film: "Wholly in accord with the thesis (later advocated in psychology of art) that the aesthetic sphere only ever involves partial illusion and that complete deception can therefore be ruled out, Mendelssohn too holds that the aesthetic illusion unfolds its power in the perfection of the faculty of imagination and judgment." Ibid., pp. 52-53.

25. Ibid., p. 52 .

26. Frank R. Ankersmit, Die historische Erfahrung, Berlin 2012, p. 43. On improbable probability, see also the chapter "Film/history/experience" in the present volume.

27. Koch $(2016$, p. 56$)$.

28. Ibid., p. 64.

29. Ibid., p. 75 .

30. Ibid., p. 77.

31. Ibid., p. 86.

32. Lotman $(1977$, p. 210).

33. Jurij M. Lotman, Kunstals Sprache: Untersuchungen zum Zeichencharakter von Literatur und Kunst, Leipzig 1981, pp. 82-83.

34. In her illuminating essay on "world constellations," Margrit Tröhler gives the example of children making mud pies, and concludes: "For the duration of the game, this alternative world with its own logic is fully real; it is not a deception, not a phantasm, not an illusion, it is simply a semblant world [Scheinwelt], an alternative, possible world." Tröhler here likewise distances herself from the assumption of manipulative deception and, despite rejecting the term "illusion," espouses a similar position to Koch. See Margrit Tröhler, "Von Weltenkonstellationen und Textgebäuden: Fiktion-Nichtfiktion-Narration in Spiel- und Dokumentarfilm," montage AV 11:2, 2002, p. 18.

35. See Mattias Frey, "The Authenticity Feeling: Language and Dialect in the Historical Film," 2018, https://film-history.org/approaches/ authenticity-feeling (last accessed May 1, 2020).

36. Roland Barthes, Camera Lucida: Reflections on Photography, New York 1981, p. 79.

37. Jean-Louis Comolli writes, "The spectacle is always a game. It requires the participation of the spectators not as consumers but as players, accomplices, masters of the game, even, if they are also its stakes. The simulacrum does not fool a 'passive' spectator (there are no 'passive' spectators): the spectator has to participate in his own fooling; the simulacrum is the means whereby he is helped to fool himself." Jean-Louis Comolli, "A Body Too Much," Screen 19:2, 1978, p. 46. 
38. Christian Metz, cited in Margrit Tröhler and Guido Kirsten (eds.), Christian Metz and the Codes of Cinema: Film Semiology and Beyond, Amsterdam 2018, p. 31.

39. Ibid.

40. According to Barthes, the reality effect is produced by signification of "the real" in which "the very absence of the signified, to the advantage of the referent alone, becomes the very signifier of realism." Roland Barthes, "The Reality Effect," in his The Rustle of Language, Berkeley 1989, p. 148.

41. Alison Landsberg, Prosthetic Memory: The Transformation of American Remembrance in the Age of Mass Culture, New York 2004, p. 2. I explore this aspect of histospheres in more detail later in the present volume, in the section "Prosthetic postmemory."

42. Baudrillard refers here to Stanley Kubrick's BARRY LYNDON (1975), whose visual design imitates the aesthetics of nineteenth-century paintings in order to represent the eighteenth century. Jean Baudrillard, Simulacra and Simulation, Ann Arbor 1994, p. 46.

43. Eric Rohmer defines "image space" [Bildraum] as follows: "The film image projected onto the rectangle of the screen, however fleeting or mobile it is, is perceived and judged as a more or less faithful, more or less beautiful depiction of part of the external world." Eric Rohmer, Murnaus Faustfilm: Analyse und szenisches Protokoll, Munich and Vienna 1980, p. 10.

44. Simon Rothöhler, "Steven Spielbergs LINCOLN: Wie ein konventionelles Biopic," taz.de, January 23, 2013, www.taz.de/!5074753 (last accessed May 1, 2020).

45. Oliver Schmidt, Hybride Räume: Filmwelten im Hollywood-Kino der Jahrtausendwende, Marburg 2013, p. 39.

46. Hermann Kappelhoff defines "the space of narrative action" [Handlungsraum] as an a priori given space within which movement "takes on an intentional direction, a sense in the logic of the fictional activity of the protagonists." Hermann Kappelhoff, The Politics and Poetics of Cinematic Realism, New York 2015, p. 28.

47. As Béla Balázs observes, visual and aural strategies to create an impression of continuity ensure the homogeneity of the filmic world: "The director achieves this by having every detail point beyond its frame into another frame that is shown to us in the next montage image. This pointingbeyond is effected through continuity of movement into the next frame, through continuity of an object, a form, that protrudes into the next image. It is often effected through looks and gestures that correspond to the looks and gestures in the next frame. It is very often effected through sound that plays across the frames, through words spoken across the frames." Béla Balázs, "Zur Kunstphilosophie des Films," in Franz-Josef Albersmeier (ed.), Texte zur Theorie des Films, Stuttgart 1998, p. 217. 
48. Rohmer describes "filmic space" [Filmraum] as follows: "In truth, the spectator does not have the illusion of the space that was actually filmed, but of a virtual space that they assemble in their imagination using the fragmentary pieces provided by the film." Rohmer (1980, p. 10).

49. Schmidt (2013, p. 76).

50. Ibid., p. 34.

51. Ibid., p. 10.

52. On the spatial turn, see for instance Stephan Günzel (ed.), Raumwissenschaften, Frankfurt 2009; Jörg Döring and Tristan Thielmann (eds.), Spatial Turn: Das Raumparadigma in den Kultur- und Sozialwissenschaften, Bielefeld 2015.

53. Schmidt (2013, p. 36).

54. Ibid., p. 34.

55. Schmidt (2013, p. 85).

56. Ibid., p. 82.

57. Kappelhoff speaks in this connection of "the figuration of spatial modulations." Hermann Kappelhoff, "Die vierte Dimension des Bewegungsbildes: Das filmische Bild im Übergang zwischen individueller Leiblichkeit und kultureller Fantasie," in Kathrin Fahlenbrach, Anne Bartsch, and Jens Eder (eds.), Audiovisuelle Emotionen: Emotionsdarstellung und Emotionsvermittlung durch audiovisuelle Medienangebote, Cologne 2007, pp. 301-302.

58. Kappelhoff $(2015$, p. 29).

59. Schmidt $(2013$, p. 128).

60. It is this aspect that makes the historical film genre so attractive to those who wish to use cinema as propaganda, for they see in historical films the potential to mold the depicted historical worlds to their own ideas and to subtly integrate new readings of history into the film's picture of the world. See for instance Rainer Rother's analysis of the Bismarck films made under the Third Reich: Rainer Rother, "Die Geschichte soll als Mythos zu uns sprechen': Bismarck im NS-Spielfilm," in Rainer Rother, Zeitbilder: Filme des Nationalsozialismus, Berlin 2019, pp. 168-190.

61. On the concept of "chronotope," see Mikhail Bakhtin, "Forms of Time and of the Chronotope in the Novel," in Mikhail Bakhtin, The Dialogic Imagination: Four Essays, Austin 1981, p. 84.

62. When Michel Foucault describes the twentieth century as the epoch of space, he is deploying a concept of space that also involves a temporal dimension, the spatial arrangement of simultaneity: "We are in the epoch of simultaneity: we are in the epoch of juxtaposition, the epoch of the near and far, of the side-by-side, of the dispersed. We are at a moment, I believe, when our experience of the world is less that of a long life developing through time than that of a network that connects points and inter- 
sects with its own skein.” Michel Foucault, “Of Other Spaces: Utopias and Heterotopias," 1984, http://web.mit.edu/allanmc/www/foucault l.pdf (last accessed May 1, 2020), p. 1.

63. Kappelhoff (2007, p. 297), and Erwin Panofsky, "Style and Medium in the Motion Pictures," in his Three Essays on Style, Cambridge, MA, and London 1995, p. 96.

64. Béla Balázs, Theory of the Film: Character and Growth of a New Art, Scotts Valley 2015, p. 140.

65. Rayd Khouloki, Der filmische Raum: Konstruktion, Wabrnehmung, Bedeutung, Berlin 2007, p. 182.

66. See Thomas Morsch, Medienästhetik des Films: Verkörperte Wabrnehmung und ästhetische Erfabrung im Kino, Munich and Paderborn 2011, p. 178.

67. Koch (2016, p. 34).

68. Schmidt refers here again to Rohmer. Schmidt (2013, p. 81).

69. Rudolf Arnheim, Art and Visual Perception: A Psychology of the Creative Eye, Berkeley and Los Angeles 1974, pp. 374-375.

70. Siegfried Kracauer elaborates further on this close relation between history and film. His account of how the historical universe is constituted by historical works that vary in scope and distance is set out in part using film terminology. Siegfried Kracauer, History - the Last Things Before the Last, Princeton 1995, pp. 104-138.

71. See on this point Schmidt: "The use of a handheld camera bound to the path taken by a certain character thus creates a different hodological space than the 'disembodied camera' of a rapidly cut action film. The two follow different principles of movement that enable different experiences of space, which may be characteristic of their respective filmic world as a whole." Schmidt (2013, p. 102).

72. Martin Seel, "Architekturen des Films," in Gertrud Koch and Christiane Voss, "Es ist, als ob": Fiktionalität in Philosophie, Film- und Medienwissenschaft, Munich 2009, p. 154.

73. According to Schmidt, "in a particular reception situation" it is possible to "enter, traverse, and leave" the space of a film "along a particular route determined by the film's temporal architecture." Schmidt (2013, p. 103).

74. Koch (2016, p. 61).

75. The potential of film sound to create spatial continuity was also already described by Balázs. Balázs (2015, p. 54).

76. Frieder Butzmann and Jean Martin describe ambience as follows: "A gently humming tapestry of the acoustic atmosphere that constantly surrounds us and otherwise, 'in ordinary life,' goes unnoticed, the ambient noise of our surroundings, imposes a sense of realism on the viewerlisteners. The subliminal noises breathe life into the objects that form part of a scene. The scenario passes from the realm of the inanimate and the 
artificial into the realm of what can be experienced, lived, shared." Frieder Butzmann and Jean Martin, Filmgeräusch: Wahrnehmungsfelder eines Mediums, Hofheim 2012, p. 46.

77. See Rasmus Greiner, "Sonic Histospheres: Sound Design and History," 2018, https://film-history.org/approaches/sonic-histospheres (last accessed May 1, 2020).

78. Michel Chion, Audio-Vision: Sound on Screen, New York 2019, p. $73 \mathrm{ff}$.

79. Greiner (2018).

80. Béla Balázs, The Spirit of Film, in Béla Balázs: Early Film Theory, New York and Oxford 2010, p. 189.

81. Cf. Michel Chion's concept of "materializing sound indices," which give spectators information about the physical constitution of the object producing the sound and the manner of sound production. Chion (2019, p. 112).

82. See Greiner (2018). Barbara Flückiger refers to sound objects with the potential to define "a place in geographical, temporal, cultural, ethical, or social terms" as orienting sounds. Barbara Flückiger, Sound Design: Die virtuelle Klangwelt des Films, Marburg 2012, pp. 305-306.

83. It should be noted that SKY WITHOUT STARs is not a clear-cut case of historical sound design, given that it was made relatively soon after the time when it is set. In the specific example given above, we can assume that at the time of production the cash register used in the film would not yet have been regarded as a historical artifact in the way that it appears to us from a twenty-first-century perspective.

84. The use of soundscapes as an aesthetic device is a product of New Hollywood cinema that quickly became established in international commercial cinema too.

85. Cf. Chion's concept of "added value." Chion (2019, p. 202).

86. Margrit Tröhler, Offene Welten ohne Helden: Plurale Figurenkonstellationen im Film, Marburg 2007, p. 15.

87. To more precisely distinguish between different variants of this concept, Tröhler introduces the notions of the group character, the character ensemble, and the character mosaic. The group character was most commonly used in early historical films with a propagandistic hue, such as BATTLESHIP POTEMKIN (1925; dir. Sergei Eisenstein), to present a crosssection of society, and can be largely ignored for present purposes. More important for post-1945 historical films are the character ensemble and the character mosaic. Tröhler emphasizes that both concepts represent an open-ended mesh of relationships in which there occur "myriad movements and redistributions between social groups, between generations and genders." Ibid., pp. 13, 209.

88. Ibid.

89. Ibid., p. 211. 
90. Tröhler explains this notion, based on Bakhtin's notion of the "chronotope" (Bakhtin 1981, p. 84), as follows: "The moment of encounter unites the spatial and temporal destinations of the characters at a central location, constitutes this location as a diegetic space, and collects together the lines of the narrative: The simultaneous and consecutive contiguity of stories and narrative strands creates, in 'chance simultaneity' and 'chance nonsimultaneity,' the foundation for closeness and distance.” Ibid., p. 214.

91. Joan K. Bleicher, "Darstellung von Geschichte in Mehrteilern und Serie: Individuelle und kollektive Erinnerungen durch Geschichte in Geschichten," SPIEL. Neue Folge: Eine Zeitschrift zur Medienkultur 2:2, 2016 , p. 24.

92. Tröhler (2007, p. 387).

93. Ibid., p. 388.

94. Ibid., p. 16.

95. See the section "Reminiscence triggers" in the present volume.

96. Tröhler $(2007$, p. 542).

97. Mise-en-scène organizes filmic space by generating "symmetries or asymmetries, statics or dynamics" and "structuring proportions stably or unstably, homogeneously or heterogeneously." Ivo Ritzer, Die Medialität der Mise-en-scène: Zur Archäologie telekinematischer Räume, Wiesbaden 2017, p. 67.

98. "What is filmed is intimately related to how it is filmed, which is intimately related to how what is filmed is contextualized. The telecinematic mise-en-scène thus operates both paradigmatically and syntagmatically. It decides what the camera records, it decides how the camera records, and it decides how the shots recorded by the camera are combined." Ibid., p. 117.

99. One way in which our perceptions can be directed is by relative proportions. See ibid., p. 67.

100. Mise-en-scène "composes into the depths [of an image], creates volume and planes, thus giving bodies their spatial presence, layering what we can see into foreground, midground, and background." Ibid., pp. 79 and 88.

101. Film sound constructs a relative off-screen space, an invisible but palpable cinematic space formed by soundscapes and ambiences as well as by individual sound objects. See also the section "Space, time, and filmic world" later in this chapter.

102. Ritzer notes that mise-en-scène, as "artistic [inszenatorisch] signifier," is not the form of the medium itself, but rather its "aesthetic structuring." Ritzer (2017, p. 67).

103. Mise-en-scène thus represents a performative practice: "A process of articulation that, through the work of production within a system, situates its parts relative to one another," which can comprise "denotative-narrative signification of a particular relation between body and space [...] 
expressive-representational evocation of affects at the level of fiction and reception, $[\ldots]$ symbolic-connotative signaling of abstract ideas through the spatial arrangement of bodies, or ornamental-decorative presentation of aesthetic forms and patterns." Ibid., pp. 65-66.

104. Ritzer describes mise-en-scène's medial quality as follows: It is "a signifying communicative entity embedded in a technological medium that occurs historically in varying contexts" and conveys potential aesthetic meanings. Ibid., p. 66.

105. See also on this point Ritzer's exposition of mise-en-scène: "Mise-en-scène comprises both what the media assemblage allows us to see and hear in the scenic space and the way in which it allows us to see and hear it in the scenic space. Mise-en-scène gives the medium its form of representation by constantly selecting from a repertoire of available methods and structurally accumulating these selected methods." Ibid., p. 97.

106. On this construal as a narrative act, mise-en-histoire bears similarities to Paul Ricœur's concept of mise-en-intrigue (emplotment). See Paul Ricœur, Time and Narrative, vol. 2, Chicago and London 1984, p. 4.

107. As well as the specific qualities of historical film stock (definition, granularity, color, contrast, etc.) and the use of historical lenses and sound technology (or simulations thereof), this can also include historical strategies of visual and sound design and the way in which sequences are narratively resolved.

108. See also Panofsky's remarks on the spatialization of time and dynamization of space. Panofsky (1995, p. 96).

109. Bakhtin (1981, p. 84).

110. Ibid., p. 84 .

111. Ritzer (2017, p. 109).

112. Hayden White, "The Question of Narrative in Contemporary Historical Theory," History and Theory 23:1, 1984, pp. 1-33.

113. Bakhtin (1981, p. 250).

114. Ritzer (2017, p. 122).

115. Ibid., p. 83.

116. Ibid.

117. Karl Prümm, "Von der Mise en scène zur Mise en images: Plädoyer für einen Perspektivenwechsel in der Filmtheorie und Filmanalyse," in Thomas Koebner and Thomas Meder (eds.), Bildtheorie und Film, Munich 2006, p. 16.

118. Ritzer (2017, p. 94$)$.

119. Ibid., p. 88.

120. As noted previously, "seeing" should be understood here as synonymous with all aspects of a film's perception, including hearing.

121. Sobchack (1992, p. 56). 
122. Walter Benjamin, "The Work of Art in the Age of Mechanical Reproduction," in his Illuminations, New York 2007, pp. 211-244.

123. Ritzer (2017, p. 76).

124. Ibid.

125. Friedrich Kittler, Gramophone, Film, Typewriter, Stanford 1999, p. 14.

126. Ritzer (2017, p. 96).

127. Ibid., p. 76.

128. Ibid.

129. See Tabea Pauli, “400 Meter Ku'damm auf der Richard-Wagner-Straße," Der Tagesspiegel, September 25, 2015, www.tagesspiegel.de/berlin/ bezirke/charlottenburg-wilmersdorf/dreharbeiten-in-berlin-400-meterkudamm-auf-der-richard-wagner-strasse/12364976.html (last accessed May 1, 2020).

130. Balázs $(2015$, p. 47$)$.

131. Jameson speaks of a film's “1930s-ness" or “1950s-ness” and criticizes intertextuality as "a deliberate, built-in feature of the aesthetic effect and as the operator of a new connotation of 'pastness' and pseudohistorical depth, in which the history of aesthetic styles displaces 'real' history." Fredric Jameson, Postmodernism, or, The Cultural Logic of Late Capitalism, London 2008, pp. 19-20.

132. For Rancière, a film's historicity lies in the "type of plot of which the film consists," in the "function of remembering that it serves," and "in the way it bears witness to the sharing of a common fate." Jacques Rancière, "Die Geschichtlichkeit des Films," in Eva Hohenberger and Judith Keilbach (eds.), Die Gegenwart der Vergangenheit: Dokumentarfilm, Fernseben und Geschichte, Berlin 2003, pp. 232-233.

133. Kracauer (1995, p. 58). Kracauer draws frequent comparisons between the activity of the photographer or filmmaker and that of the historian. For instance, both must select and structure their material, and both refer to a larger referent outside the picture/historical work. See ibid., pp. 53-58.

134. Ibid., p. 53.

135. Anne Rutherford, "Precarious Boundaries: Affect, Mise en Scene and the Senses in Angelopoulos' Balkans Epic," in Richard Candida-Smith (ed.), Art and the Performance of Memory: Sounds and Gestures of Recollection, London and New York 2006, p. 67.

136. Ritzer (2017, p. 78).

137. Ibid.

138. See also the chapter "Film/history/experience."

139. Sobchack (1992, pp. 138-140).

140. Ritzer (2017, p. 79).

141. Ricœur (1984).

142. Ankersmit (2012, p. 43 ). 
143. Landsberg (2004, p. 2).

144. Stephen Prince develops the notion of perceptual realism in his study of digital images: "A perceptually realistic image is one which structurally corresponds to the viewer's audiovisual experience of three-dimensional space. Perceptually realistic images correspond to this experience, because film-makers build them to do so. Such images display a nested hierarchy of cues which organize the display of light, color, texture, movement, and sound in ways that correspond with the viewer's own understanding of these phenomena in daily life. Perceptual realism, therefore, designates a relationship between the image and the spectator, and it can encompass both unreal images and those which are referentially realistic. Because of this, unreal images may be referentially fictional but perceptually realistic." These general reflections can also be applied to analog film images and their relation to history. Stephen Prince, "True Lies: Perceptual Realism, Digital Images, and Film Theory," Film Quarterly 49:3, 1996, p. 32.

145. This idea is based on Baudrillard's thesis that cinema has contributed to the disappearance of history and rise of the archive. Baudrillard (1994, p. 48).

146. Sobchack (1992, p. 56).

147. Ibid., pp. 138-140.

\section{BIBLIOGRAPHY}

Frank R. Ankersmit, Die historische Erfahrung, Berlin 2012.

Rudolf Arnheim, Art and Visual Perception: A Psychology of the Creative Eye, Berkeley and Los Angeles 1974.

Erich Auerbach, Mimesis: The Representation of Reality in Western Literature, Princeton 2003.

Mikhail Bakhtin, The Dialogic Imagination: Four Essays, Austin 1981.

Béla Balázs, Theory of the Film: Character and Growth of a New Art, Scotts Valley 2015.

Béla Balázs, The Spirit of Film, in Béla Balázs: Early Film Theory, New York and Oxford 2010.

Béla Balázs, "Zur Kunstphilosophie des Films," in Franz-Josef Albersmeier (ed.), Texte zur Theorie des Films, Stuttgart 1998, pp. 201-223.

Roland Barthes, "The Reality Effect," in his The Rustle of Language, Berkeley 1989. Roland Barthes, Camera Lucida: Reflections on Photography, New York 1981. Jean Baudrillard, Simulacra and Simulation, Ann Arbor 1994.

Walter Benjamin, "The Work of Art in the Age of Mechanical Reproduction," in his Illuminations, New York 2007, pp. 211-244.

Joan K. Bleicher, "Darstellung von Geschichte in Mehrteilern und Serie: Individuelle und kollektive Erinnerungen durch Geschichte in Geschichten," SPIEL. Neue Folge: Eine Zeitschrift zur Medienkultur 2:2, 2016, pp. 21-37. 
Frieder Butzmann and Jean Martin, Filmgeräusch: Wahrnehmungsfelder eines Mediums, Hofheim 2012.

Michel Chion, Audio-Vision: Sound on Screen, New York 2019.

Jean-Louis Comolli, “A Body Too Much,” Screen 19:2, 1978, pp. 41-54.

Jörg Döring and Tristan Thielmann (eds.), Spatial Turn: Das Raumparadigma in den Kultur- und Sozialwissenschaften, Bielefeld 2015.

Barbara Flückiger, Sound Design: Die virtuelle Klangwelt des Films, Marburg 2012.

Michel Foucault, "Of Other Spaces: Utopias and Heterotopias," 1984, http:// web.mit.edu/allanmc/www/foucaultl.pdf (last accessed May 1, 2020).

Mattias Frey, "The Authenticity Feeling: Language and Dialect in the Historical Film," 2018, https://film-history.org/approaches/authenticity-feeling (last accessed May 1, 2020).

Rasmus Greiner, "Sonic Histospheres: Sound Design and History," 2018, https://film-history.org/approaches/sonic-histospheres (last accessed May 1, 2020).

Stephan Günzel (ed.), Raumwissenschaften, Frankfurt 2009.

Hermann Kappelhoff, The Politics and Poetics of Cinematic Realism, New York 2015.

Hermann Kappelhoff, "Die vierte Dimension des Bewegungsbildes: Das filmische Bild im Übergang zwischen individueller Leiblichkeit und kultureller Fantasie," in Kathrin Fahlenbrach, Anne Bartsch, and Jens Eder (eds.), Audiovisuelle Emotionen: Emotionsdarstellung und Emotionsvermittlung durch audiovisuelle Medienangebote, Cologne 2007, pp. 297-311.

Rayd Khouloki, Der filmische Raum: Konstruktion, Wabrnehmung, Bedeutung, Berlin 2007.

Friedrich Kittler, Gramophone, Film, Typewriter, Stanford 1999.

Gertrud Koch, Die Wiederkehr der Illusion: Der Film und die Kunst der Gegenwart, Berlin 2016.

Siegfried Kracauer, Theory of Film: The Redemption of Physical Reality, Princeton 1997.

Siegfried Kracauer, History — the Last Things Before the Last, Princeton 1995.

Alison Landsberg, Prosthetic Memory: The Transformation of American Remembrance in the Age of Mass Culture, New York 2004.

Yuri [Jurij] M. Lotman, Universe of the Mind: A Semiotic Theory of Culture, Bloomington and Indianapolis 1990.

Jurij M. Lotman, Kunst als Sprache: Untersuchungen zum Zeichencharakter von Literatur und Kunst, Leipzig 1981.

Jurij Lotman, The Structure of the Artistic Text, Ann Arbor 1977.

Thomas Morsch, Medienästhetik des Films: Verkörperte Wabrnehmung und ästhetische Erfabrung im Kino, Munich and Paderborn 2011.

Erwin Panofsky, Three Essays on Style, Cambridge, MA, and London 1995. 
Karl Prümm, "Von der Mise en scène zur Mise en images: Plädoyer für einen Perspektivenwechsel in der Filmtheorie und Filmanalyse," in Thomas Koebner and Thomas Meder (eds.), Bildtheorie und Film, Munich 2006, pp. 15-35.

Paul Ricœur, Time and Narrative, vol. 3, Chicago and London 1985.

Paul Ricour, Time and Narrative, vol. 2, Chicago and London 1984.

Paul Ricœur, Time and Narrative, vol. 1, Chicago and London 1984.

Ivo Ritzer, Die Medialität der Mise-en-scène: Zur Archäologie telekinematischer Räume, Wiesbaden 2017.

Eric Rohmer, Murnaus Faustfilm: Analyse und szenisches Protokoll, Munich and Vienna 1980.

Rainer Rother, Zeitbilder: Filme des Nationalsozialismus, Berlin 2019.

Simon Rothöhler, "Steven Spielbergs LINCOLN: Wie ein konventionelles Biopic," taz.de, January 23, 2013, www.taz.de/!5074753 (last accessed May 1, 2020).

Oliver Schmidt, Hybride Räume: Filmwelten im Hollywood-Kino der Jahrtausendwende, Marburg 2013.

Martin Seel, "Architekturen des Films," in Gertrud Koch and Christiane Voss, "Es ist, als ob": Fiktionalität in Philosophie, Film- und Medienwissenschaft, Munich 2009, pp. 151-161.

Vivian Sobchack, The Address of the Eye: A Phenomenology of Film Experience, Princeton 1992.

Margrit Tröhler, Offene Welten ohne Helden: Plurale Figurenkonstellationen im Film, Marburg 2007.

Margrit Tröhler, "Von Weltenkonstellationen und Textgebäuden: Fiktion Nichtfiktion - Narration in Spiel- und Dokumentarfilm," montage AV $11: 2,2002$.

Margrit Tröhler and Guido Kirsten (eds.), Christian Metz and the Codes of Cinema: Film Semiology and Beyond, Amsterdam 2018.

Hayden White, "Historiography and Historiophoty," American Historical Review 93:5, 1988, pp. 1193-1199.

Hayden White, "The Question of Narrative in Contemporary Historical Theory," History and Theory 23:1, 1984, pp. 1-33.

\section{Filmography}

Barry Lyndon; dir. Stanley Kubrick; United Kingdom, USA 1975.

Battleship Potemkin (Бронено́сец "Потёмкин"); dir. Sergei Eisenstein; Soviet Union 1925.

Dunkirk; dir. Christopher Nolan; United Kingdom, USA, France, Netherlands 2017.

Ku'damm 56; dir. Sven Bohse; Germany 2016.

Saving Private Ryan; dir. Steven Spielberg; USA 1998.

Sky without Stars (Himmel ohne Sterne); dir. Helmut Käutner; Federal Republic of Germany 1955. 
Open Access This chapter is licensed under the terms of the Creative Commons Attribution 4.0 International License (http://creativecommons.org/licenses/ by $/ 4.0 /$ ), which permits use, sharing, adaptation, distribution and reproduction in any medium or format, as long as you give appropriate credit to the original author(s) and the source, provide a link to the Creative Commons licence and indicate if changes were made.

The images or other third party material in this chapter are included in the chapter's Creative Commons licence, unless indicated otherwise in a credit line to the material. If material is not included in the chapter's Creative Commons licence and your intended use is not permitted by statutory regulation or exceeds the permitted use, you will need to obtain permission directly from the copyright holder. 